\title{
Pulmonary Complications in Candidates for Liver Transplantation
}

\author{
Niloofar Razavi-Khorasani ${ }^{1}$, Bobak Moazzami ${ }^{1}$, Arash Dooghaie Moghadam ${ }^{1}$, Pegah Eslami ${ }^{1}$, Ermia Farokhi ${ }^{1}$, \\ Azim Mehrvar ${ }^{2}$, Sandra Saeedi ${ }^{3}$, Shahrokh Iravani ${ }^{2}$, Morteza Aghajanpoor Pasha ${ }^{3}$, Mohssen Nassiri Toosi ${ }^{1, *}$
}

1. Liver Transplantation Research Center, Tehran University of Medical Sciences, Tehran, Iran

2. Research Center for Cancer Screening and Epidemiology, AJA University of Medical Sciences, Tehran, Iran

3. Gastroenterology and Hepatobiliary Research Center, AJA University of Medical Sciences, Tehran, Iran

\footnotetext{
* Corresponding Author:

Mohssen Nassiri Toosi, MD

Department of Liver Transplantation, Imam Khomeini Hospital, Keshavarz

Blvd, Tehran, Iran

Tel: +982166581598

Fax: + 982166581521

Email: nasirito@sina.tums.ac.ir
}

Received: 25 Dec. 2019

Accepted: 10 May. 2020

\section{ABSTRACT}

The liver plays a pivotal role in maintaining the homeostasis of various organ systems. Also, end-stage liver disease and its complications are major causes of morbidity and mortality among adults. Individuals who develop a chronic liver disease are at increased risk of progression to multi-organ dysfunction, including the pulmonary system. The clinical complications of pulmonary problems related to the presence of liver disease range from mild (such as hypoxemia) to life-threatening diseases (such as portopulmonary hypertension and hepatopulmonary syndrome). Herein, the major pulmonary complications related to liver cirrhosis and considerations for performing liver transplantation are reviewed.

\section{KEYWORDS:}

Cirrhosis, Hypoxemia, Liver transplantation, Hepatopulmonary syndrome, Portopulmonary hypertension, Lung diseases

Please cite this paper as:

Razavi-Khorasani N, Moazzami B, Dooghaie Moghadam A, Eslami P, Farokhi E, Mehrvar A, Saeedi S, Iravani S, Aghajanpoor Pasha M, Nassiri Toosi M. Pulmonary Complications in Candidates for Liver Transplantation. Middle East J Dig Dis 2020;12:145-153. doi: 10.34172/ mejdd.2020.176.

\section{INTRODUCTION}

End-stage liver disease (ESLD) and its associated complications are currently included in the significant causes of death globally among adult population. ${ }^{1-3}$ Currently, orthotopic liver transplantation (LT) is considered as the only viable option for the management of patients with ESLD. ${ }^{4}$ Patients with advanced liver disease often present with various coexisting organ dysfunction. ${ }^{5}$ In this respect, pulmonary disorders remain one of the major concerns among patients with ESLD who are candidates for LT. ${ }^{6-10}$ Approximately half of the patients with ESLD have been reported to suffer from pulmonary diseases. ${ }^{11} \mathrm{~A}$ wide spectrum of pulmonary conditions has been identified to be associated with advanced liver disease regardless of the etiology of liver cirrhosis. The most important pre-existing conditions that compromise lung function in patients with liver disease are concomitant cardiopulmonary disorders, autoimmune disease, and chronic obstructive pulmonary disease (COPD). ${ }^{12,13}$ In this review, we aimed to discuss the most important pulmonary complications related to liver cirrhosis and considerations for performing LT in this group of patients. 


\section{Hypoxemia associated with liver failure}

Hypoxemia is the most common pulmonary abnormality in patients with cirrhosis. ${ }^{14,15}$ The severity of chronic liver disease contributes to the development of hypoxemia and worsens the prognosis of these patients. ${ }^{16,17}$ The underlying pathophysiology of hypoxemia in patients with cirrhosis is mainly caused by abnormal pulmonary perfusion pathways. ${ }^{18}$ Previous studies suggest that a rightward shift in the oxyhemoglobin dissociation curve seen in patients with cirrhosis may be the primary physiological mechanism that explains this association. ${ }^{19}$ Moreover, several studies also have reported an evident increase in 2,3-diphosphoglycerate (2,3-DPG) as a compensatory mechanism for maintaining oxygen consumption in patients with cirrhosis. ${ }^{20,21}$ In a review article, ${ }^{22}$ it was reported that four factors played a major role in regulating the position of the oxyhemoglobin dissociation curve. These factors were $\mathrm{pH}$, body temperature, carbon dioxide content, and organic phosphates. However, further analysis indicated that a reduction in the affinity of hemoglobin for oxygen did not appear to have the capacity to significantly affect arterial oxygen saturation. ${ }^{23}$ In the cohort study done by Clerbaux and colleagues, ${ }^{19}$ it was shown that several additional factors contributed to changing the position of oxyhemoglobin dissociation curve such as alteration of the enzymes controlling the phosphoglycerate shunt, hypothyroidism, the type of treatment received by patients (e.g., diuretics and/or propranolol), and acid-base disturbances.

The presence of hypoxemia among patients with cirrhosis suggests that the liver plays a detrimental role in the underlying pathogenesis of this condition. The impact of chronic liver disease on the oxygen saturation of blood may explain the abnormal increase in the alveolar-arterial oxygen gradient among patients awaiting LT. ${ }^{24}$ In addition, the improvement of cirrhosis-related hypoxemia after performing LT suggests the role of liver disease in causing hypoxemia.

\section{Chronic obstructive pulmonary disease (COPD)}

The pre-existing COPD is common among LT candidates. ${ }^{25}$ In this regard, Ehlers and co-workers ${ }^{26}$ analyzed the lifetime pre- and post-LT prevalence rates of smoking among $202 \mathrm{LT}$ recipients and found that $60 \%$ of these patients had a history of smoking. Similarly, another study reported that the history of smoking existed in approximately $60 \%$ of LT candidates and $27 \%$ were current smokers. Clinically significant COPD, defined as FEV1/FVC $<70 \%$, was present in only $18 \%$ of these patients. Moreover, the prior diagnosis of COPD was not made in $80 \%$ of those patients. ${ }^{25}$ Currently, there is no consensus regarding the safety of patients with COPD who are candidates for LT. One study suggested that the 5-year survival rate of patients with advanced cirrhosis who underwent LT was about $24-30 \%$ among those with FEV1 $<30 \%$ predicted..$^{27,28}$ It is notable that most of these patients may have a prolonged history of smoking, which may result in an increased risk of lung malignancy.

Spirometry is the most frequently performed lung function test. A recently developed lung function measurement tool showed better prognostic capabilities, compared with spirometry, for patients with COPD. The BODE index, which is based on Body mass index (BMI), airway Obstruction, Dyspnea scale, and Exercise capacity, could predict the risk of mortality from any respiratory causes regardless of the FEV1-based classification. The BODE index assesses several additional risk factors, such as the evidence of hypoxemia, severe dyspnea, body-mass index, and 6-minute walking test. Thus, this grading system should be used more widely among LT candidates with COPD because of its better risk assessment. $^{29}$

\section{Hepatopulmonary syndrome (HPS)}

Hepatopulmonary syndrome (HPS) is defined by portal hypertension with or without concomitant liver cirrhosis, pulmonary gas exchange abnormalities, and arterial hypoxemia caused by intrapulmonary vascular dilatations. ${ }^{30-34}$ (Figure 1). Approximately, $4-47 \%$ of patients with documented liver cirrhosis and $4-32 \%$ of candidates for LT are diagnosed with HPS. ${ }^{35-38}$ The most prominent clinical feature of HPS is progressive dyspnea and low oxygen saturation levels. ${ }^{39}$ The progressive decline of lung function 


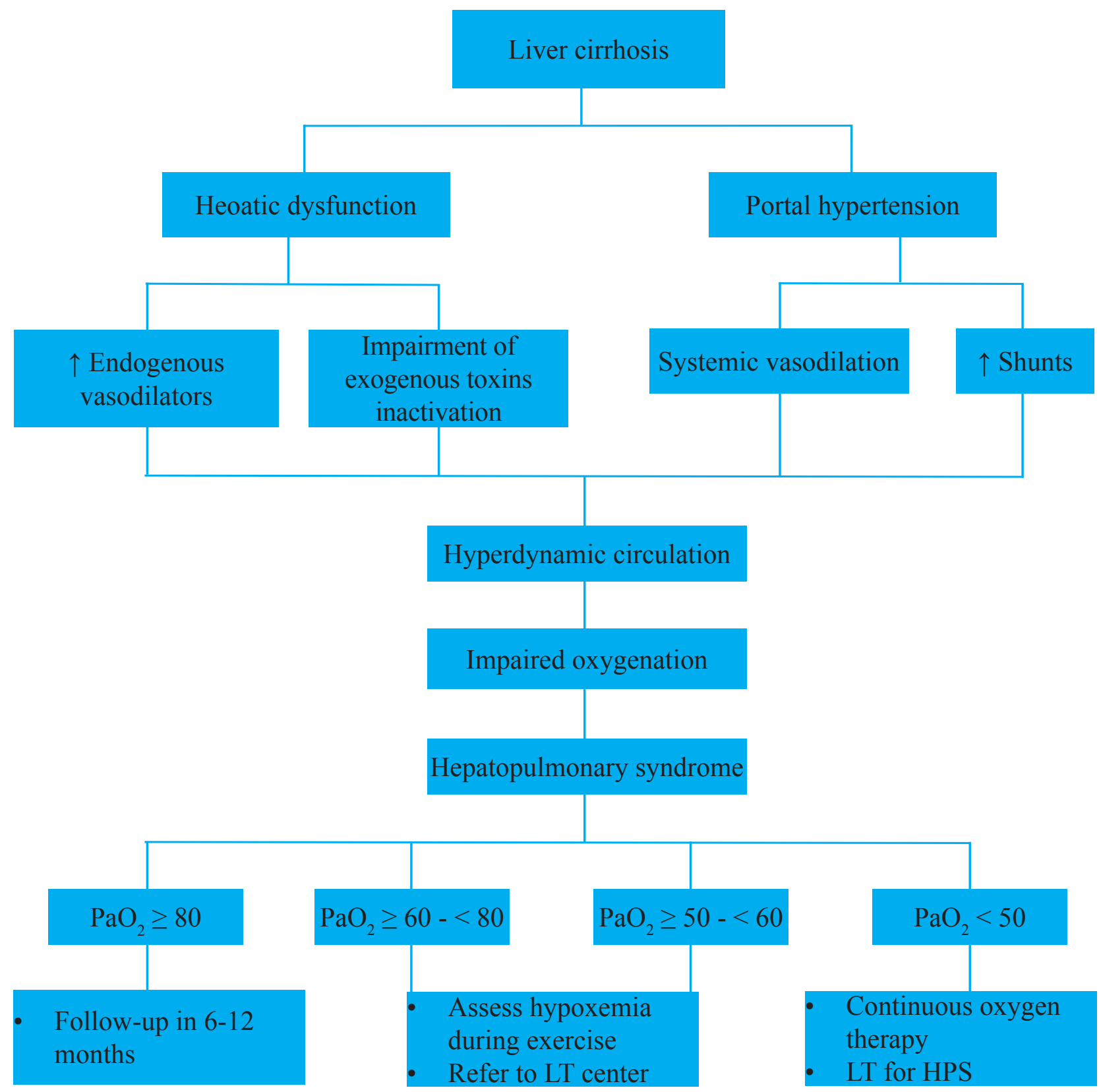

Fig.1: Algorithm depicting the diagnostic and pathophysiology approach to hepatopulmonary syndrome ${ }^{34}$

occurs regardless of stable liver function. ${ }^{40}$ These patients often experience cyanotic nail beds and clubbed fingers. Supplemental oxygen therapy is often needed for managing hypoxemia in more advanced HPS cases. Currently, the only viable option for the management of HPS is liver transplantation, which is followed by an improved lung function within about 1 year. ${ }^{41}$ Despite advances in post-liver transplantation care and monitoring of the recipi- ents, the presence of HPS is still associated with extremely poor prognosis. In a cohort study, Schenk and colleagues reported that the presence of HPS before transplantation was an independent risk factor for higher mortality rate in patients with cirrhosis. ${ }^{42}$ The median survival time among patients with cirrhosis and concomitant HPS was significantly lower compared with patients with cirrhosis but without HPS (10.6 months vs. 40.8 months, re- 
spectively). Moreover, the overall mortality incidence among patients with HPS was about $63 \%$ during 2.5 years of follow-up duration. The major cause of death was due to gastrointestinal bleeding leading to hemorrhagic shock. ${ }^{42}$ Another study reported that the mortality rate among 22 patients with HPS was $41 \%$ after the establishment of the diagnosis. In addition, Swanson and others showed that arterial hypoxemia was a major risk factor that influences survival outcome. ${ }^{16}$ According to these previous reports, the survival rates following LT are markedly lower in HPS cases when compared with those without HPS. Hence, an in-depth individual analysis is required for those HPS cases that have severe hypoxemia $\left(\mathrm{PaO}_{2} \leq 50 \mathrm{mmHg}\right)$ prior to the final acceptance as LT candidates. At the same time, it should be noted that severe HPS cases have an extremely poor survival rate without transplantation, and therefore, it is considered as a criterion for prioritizing organ allocation. Accordingly, a great debate still remains whether the allocation of scarce life-saving resources should include patients with HPS or that should be allocated to potentially more clinically stable candidates. ${ }^{16,43-45}$

\section{Portopulmonary hypertension (POPH)}

Portopulmonary hypertension (POPH) is defined as the coexistence of intrapulmonary vasoconstriction in the setting of portal hypertension (caused by chronic liver disease or extrahepatic causes). ${ }^{46}$ Patients must meet the following diagnostic criteria including elevated resting mean pulmonary artery pressure more than $25 \mathrm{mmHg}$ at right heart catheterization, evidence of pulmonary capillary wedge pressure (PCWP) less than $15 \mathrm{mmHg}$, and a pulmonary vascular resistance greater than 240 dynes/s/ $\mathrm{cm}-5 .{ }^{47,48}$ Although POPH is a relatively rare condition, it is most commonly seen in patients with ESLD. Overall, this condition is found in approximately $2-8.5 \%$ of patients with liver cirrhosis and liver transplant candidates. ${ }^{49-52}$ Based on the French National Center for pulmonary artery hypertension, POPH comprises nearly $10 \%$ of referred patients as a consequence of cirrhosis severity and poor cardiac function. $^{53}$
POPH is generally asymptomatic and is usually detected with suspicious changes on screening echocardiography with evidence of elevated right ventricular systolic pressure (RVSP). In high-volume transplantation centers, liver transplant candidates undergo contrast-enhanced echocardiography to identify pre-existing POPH. Moreover, the suspected cases should be followed with right heart catheterization if elevated RVSP is detected on echocardiogram. RVSP can be calculated from the tricuspid regurgitant (TR) jet velocity using the modified Bernoulli equation ([RSVP $=4 \times(\mathrm{TR}) 2+\mathrm{RAP}])$, in which the mean right atrial pressure (RAP) remains constant at $10 \mathrm{~mm} \mathrm{Hg} .{ }^{54-56}$ Right heart catheterization is performed if the RSVP is greater than $50 \mathrm{~mm} \mathrm{Hg}$. The 50-mm Hg threshold for RSVP is associated with $97 \%$ sensitivity and $77 \%$ specificity for the diagnosis of POPH. ${ }^{57,58}$ The most common presenting symptom among LT candidates is fatigue and exertional dyspnea and is not easily differentiated from general signs and symptoms of liver problems. Although syncope or chest pain is usually found in LT candidates with severe $\mathrm{POPH}$ and right heart failure, the lack of these symptoms should not rule out the possibility of POPH.

\section{Autoimmune diseases}

Autoimmune diseases can affect various parts of the body, most often the lung and liver. ${ }^{59}$ It has been estimated that nearly half of the patients with rheumatoid arthritis develop lung diseases such as chronic pleural effusion, pulmonary parenchymal disease (e.g., interstitial pneumonitis), pulmonary fibrosis, and pulmonary vasculature (e.g., pulmonary hypertension). ${ }^{60,61}$ In addition, the therapeutic regimen used for controlling inflammation and symptoms related to these autoimmune conditions is independently associated with the development of liver disease. Liver damage caused by the widespread use of anti-inflammatory drugs, including high dose non-steroidal anti-inflammatory drugs, antirheumatic drugs (e.g. methotrexate), and tumor necrosis factor inhibitors have shown to significantly accelerate the process of liver and lung injury. ${ }^{62,63}$

Pulmonary manifestations of autoimmune disorders 
are complex and may be associated with the involvement of airway and/or lung parenchyma. ${ }^{64}$ Although nonspecific symptoms of pulmonary involvement may occur in the early stages of autoimmune disorders, the diagnosis of liver involvement precedes or is diagnosed concurrently with pulmonary manifestation. ${ }^{65}$ The most common indications for autoimmune-related LT include primary biliary cirrhosis, primary sclerosing cholangitis, and autoimmune hepatitis. ${ }^{66,67}$ Pulmonary complications, including lymphocytic interstitial pneumonia, bronchiolitis obliterans, obstructive airway disease, and pulmonary hypertension, are frequently seen in these groups of patients. ${ }^{68,69}$ Moreover, these patients are at increased risk of autoimmune hepatitis development and also parenchymatous liver diseases such as nodular regenerative hyperplasia. ${ }^{70}$ Other autoimmune disorders, including dermatomyositis, scleroderma, and systemic lupus erythematosus, can also cause both liver and lung damages. ${ }^{71}$ The high incidence and widely diverse presentation of lung involvement in patients with autoimmunity indicate the need for a rigorous preoperative assessment of pulmonary function in LT candidates.

\section{Hepatic hydrothorax}

Hepatic hydrothorax $(\mathrm{HH})$ is defined as a large accumulation of fluid (more than $500 \mathrm{~mL}$ ) within the pleural space in the setting of liver cirrhosis and in the absence of other etiologies related to pleural effusion, such as cardiac, pulmonary, or pleural diseases. ${ }^{72,73}$ This complication occurs in about $5-10 \%$ of patients with cirrhosis. Patients with HH can be presented with severe symptoms (e.g. dyspnea, hypoxemia, and cough) with only $500 \mathrm{~mL}$ accumulation of fluid. Although the exact underlying mechanisms of HH development have not been well understood, studies suggest that the passage of ascitic fluid to the peritoneal cavity may be due to small diaphragmatic defects. Several diagnostic factors have been suggested to assist physicians in determining the causes of effusion demonstrated by thoracentesis (table 1). ${ }^{72,74,75}$ The management of $\mathrm{HH}$ is similar to those of ascites. Alcohol consumption should be extremely avoided in patients who continue active drinking. ${ }^{76}$ Moreover, dietary sodium
Table 1: Characteristics of Hepatic Hydrothorax in patients undergoing thoracentesis

\begin{tabular}{l}
\hline Location \\
\hline Right side (73-85\%) \\
\hline Left side (13-17\%) \\
\hline Bilateral (2-10\%) \\
\hline
\end{tabular}

Fluid characteristics

Cell count $<250$ polymorphonuclear cells per $\mathrm{mm}^{3}$

$\mathrm{pH}>7.4$

Protein $<2.5 \mathrm{~g} / \mathrm{dL}$

Pleural fluid/serum total protein ratio $<0.5$

Glucose level similar to that of serum

Serum-to-pleural fluid albumin gradient $>1.1 \mathrm{~g} / \mathrm{dL}$

Pleural fluid/serum bilirubin ratio $<0.6$

Pleural fluid/serum lacate dehydrogenase ratio $<0.6$

restriction, along with diuretic usage, should be considered in these patients. Finally, evaluation for liver transplantation should be considered in those patients with refractory $\mathrm{HH} .{ }^{77}$

\section{Spontaneous bacterial empyema}

Spontaneous bacterial empyema is referred to as the infected pleural fluid as the secondary complication of HH. ${ }^{78}$ Notwithstanding the term implying the presence of bacterial infection, no evidence of pus or abscess is observed in most of the cases, and therefore, its management strategy is distinct from those of empyema secondary to pneumonia. This complication has been reported to occur in approximately $13-30 \%$ of $\mathrm{HH}$ cases. ${ }^{79}$ Spontaneous bacterial empyema is associated with poor outcome and a relatively high mortality rate of more than $20 \%{ }^{80}$ The exact pathogenesis of this complication is not fully understood. However, it may be due to the spread of bacteria throughout the peritoneal cavity. Moreover, this condition could also occur even in the absence of an obvious ascites. ${ }^{81}$

\section{CONCLUSION}

Pulmonary complications related to liver cirrhosis is associated with distinct clinical features. The early recognition of these complications among patients with cirrhosis is mandatory for enhancing 
the prognosis and reducing post-liver transplantation complications. Currently, the proposed pharmacological and nonsurgical treatments have not shown promising results. However, results from prospective studies suggest the beneficial role of early LT in the reversal of pulmonary symptoms. In this regard, further clinical investigations are warranted to elucidate the mechanisms and predictors of this pulmonary involvement and possibly new treatment modalities.

\section{ETHICAL APPROVAL}

There is nothing to be declared.

\section{CONFLICT OF INTEREST}

The authors declare no conflict of interest related to this work.

\section{REFERENCES}

1. Mokdad AA, Lopez AD, Shahraz S, Lozano R, Mokdad AH, Stanaway J, et al. Liver cirrhosis mortality in 187 countries between 1980 and 2010: a systematic analysis. BMC Med 2014;12:145. doi: 10.1186/s12916-014-0145-y.

2. Bhala N, Aithal G, Ferguson J. How to tackle rising rates of liver disease in the UK. BMJ 2013;346:f807. doi: 10.1136/ bmj.f807.

3. Peng J-K, Hepgul N, Higginson IJ, Gao W. Symptom prevalence and quality of life of patients with end-stage liver disease: A systematic review and meta-analysis. Palliat Med 2019;33:24-36. doi: 10.1177/0269216318807051.

4. Russo FP, Ferrarese A, Zanetto A. Recent advances in understanding and managing liver transplantation. F1000Res 2016;5. doi: 10.12688/f1000research.8768.1.

5. Neuberger J. An update on liver transplantation: A critical review. J Autoimmun 2016;66:51-9. doi: 10.1016/j. jaut.2015.08.021.

6. Varghese J, Ilias-basha H, Dhanasekaran R, Singh S, Venkataraman J. Hepatopulmonary syndrome - past to present. Ann Hepatol 2007;6:135-42.

7. Tumgor G. Cirrhosis and hepatopulmonary syndrome. World $J$ Gastroenterol 2014;20:2586-94. doi: 10.3748/wjg.v20.i10.2586.

8. Krowka MJ, Wiesner RH, Heimbach JK. Pulmonary contraindications, indications and MELD exceptions for liver transplantation: a contemporary view and look forward. $J$ Hepatol 2013;59:367-74. doi: 10.1016/j.jhep.2013.03.026.

9. McAlister FA, Bertsch K, Man J, Bradley J, Jacka M. Incidence of and risk factors for pulmonary complications after nonthoracic surgery. Am J Respir Crit Care Med 2005;171:514-7. doi: 10.1164/rccm.200408-1069OC.

10. Yeshua H, Blendis LM, Oren R. Pulmonary manifestations of liver diseases. Semin Cardiothorac Vasc Anesth 2009;13:609. doi: 10.1177/1089253209334615.
11. Alves L, Sant'Anna CC, March Mde F, Ferreira S, Marsillac M, Tura M, et al. Preoperative pulmonary assessment of children for liver transplantation. Pediatr Transplant 2008;12:536-40. doi: 10.1111/j.1399-3046.2007.00845.x

12. Iqbal S, Smith KA, Khungar V. Hepatopulmonary Syndrome and Portopulmonary Hypertension: Implications for Liver Transplantation. Clin Chest Med 2017;38:785-95. doi: 10.1016/j.ccm.2017.08.002.

13. Houlihan DD, Holt A, Elliot C, Ferguson JW. Review article: liver transplantation for the pulmonary disorders of portal hypertension. Aliment Pharmacol Ther 2013;37:183-94. doi: 10.1111/apt.12140.

14. Krowka MJ. Pathophysiology of arterial hypoxemia in advanced liver disease. Liver Transpl Surg 1996;2:308-12. doi: 10.1002/lt.500020412.

15. Vachiery F, Moreau R, Hadengue A, Gadano A, Soupison $\mathrm{T}$, Valla D, et al. Hypoxemia in patients with cirrhosis: relationship with liver failure and hemodynamic alterations. J Hepatol 1997;27:492-5. doi: 10.1016/s01688278(97)80353-4.

16. Swanson KL, Wiesner RH, Krowka MJ. Natural history of hepatopulmonary syndrome: Impact of liver transplantation. Hepatology 2005;41:1122-9. doi: 10.1002/hep.20658.

17. Khan AN, Al-Jahdali H, Abdullah K, Irion KL, Sabih Q, Gouda A. Pulmonary vascular complications of chronic liver disease: Pathophysiology, imaging, and treatment. Ann Thorac Med 2011;6:57-65. doi: 10.4103/1817-1737.78412.

18. Sussman NL, Kochar R, Fallon MB. Pulmonary complications in cirrhosis. Curr Opin Organ Transplant 2011;16:2818. doi: 10.1097/MOT.0b013e32834664df.

19. Clerbaux T, Detry B, Geubel A, Veriter C, Liistro G, Horsmans Y, et al. The oxyhemoglobin dissociation curve in liver cirrhosis. Chest 2006;129:438-45. doi: 10.1378/ chest.129.2.438.

20. Keys A, Snell AM. Respiratory properties of the arterial blood in normal man and in patients with disease of the liver: position of the oxygen dissociation curve. J Clin Invest 1938;17:59-67. doi: 10.1172/jci100928.

21. Caldwell PRB, Fritts HW, Cournand A. Oxyhemoglobin dissociation curve in liver disease. J Appl Physiol 1965;20:31620. doi: 10.1152/jappl.1965.20.2.316.

22. Brewer GJ.2,3-DPG and erythrocyte oxygen affinity. Rev Med 1974;25:29-38. doi: 10.1146/annurev.me.25.020174.000333.

23. Astrup J, Rorth M. Oxygen affinity of hemoglobin and red cell 2,3-diphosphoglycerate in hepatic cirrhosis. Scand J Clin Lab Invest 1973;31:311-7. doi: 10.3109/00365517309082436.

24. Hourani JM, Bellamy PE, Tashkin DP, Batra P, Simmons MS. Pulmonary dysfunction in advanced liver disease: frequent occurrence of an abnormal diffusing capacity. Am J Med 1991;90:693-700. doi: 10.1016/S0002-9343(05)80057-9.

25. Rybak D, Fallon MB, Krowka MJ, Brown RS, Jr, Reinen J, Stadheim L, et al. Risk factors and impact of chronic obstructive pulmonary disease in candidates for liver trans- 
plantation. Liver Transpl 2008;14:1357-65. doi: 10.1002/ 1t. 21545 .

26. Ehlers SL, Rodrigue JR, Widows MR, Reed AI, Nelson DR. Tobacco use before and after liver transplantation: a single center survey and implications for clinical practice and research. Liver Transpl 2004;10:412-7. doi: 10.1002/lt.20087.

27. Chung LP, Winship P, Phung S, Lake F, Waterer G. Five-year outcome in COPD patients after their first episode of acute exacerbation treated with non-invasive ventilation. Respirology 2010;15:1084-91. doi: 10.1111/j.1440-1843.2010.01795.x

28. Seamark DA, Seamark CJ, Halpin DM. Palliative care in chronic obstructive pulmonary disease: a review for clinicians. $J R$ Soc Med 2007;100:225-33. doi: 10.1177/014107680710000512.

29. Celli BR, Cote CG, Marin JM, Casanova C, Montes de Oca M, Mendez RA, et al. The body-mass index, airflow obstruction, dyspnea, and exercise capacity index in chronic obstructive pulmonary disease. $N$ Engl $J$ Med 2004;350:1005-12. doi: 10.1056/NEJMoa021322.

30. Krowka MJ. Hepatopulmonary syndromes. Gut 2000;46:1-4. doi: 10.1136/gut.46.1.1

31. Rodriguez-Roisin R, Krowka MJ. Hepatopulmonary syndrome-a liver-induced lung vascular disorder. $N$ Engl $J$ Med 2008;358:2378-87. doi: 10.1056/NEJMra0707185.

32. Fuhrmann V, Krowka M. Hepatopulmonary syndrome. $J$ Hepatol 2018;69:744-5. doi: 10.1016/j.jhep.2018.01.002.

33. Soulaidopoulos S, Cholongitas E, Giannakoulas G, Vlachou M, Goulis I. Review article: Update on current and emergent data on hepatopulmonary syndrome. World J Gastroenterol 2018;24:1285-98. doi: 10.3748/wjg.v24.i12.1285.

34. Raevens S, Geerts A, Van Steenkiste C, Verhelst X, Van Vlierberghe H, Colle I. Hepatopulmonary syndrome and portopulmonary hypertension: recent knowledge in pathogenesis and overview of clinical assessment. Liver Int 2015;35:1646-60. doi: 10.1111/liv.12791.

35. Krowka MJ, Cortese DA. Hepatopulmonary syndrome. Current concepts in diagnostic and therapeutic considerations. Chest 1994;105:1528-37. doi: 10.1378/chest.105.5.1528.

36. Lange PA, Stoller JK. The hepatopulmonary syndrome. Ann Intern Med 1995;122:521-9. doi: 10.7326/0003-4819-122-7199504010-00008.

37. Stoller JK, Lange PA, Westveer MK, Carey WD, Vogt D, Henderson JM. Prevalence and reversibility of the hepatopulmonary syndrome after liver transplantation. The Cleveland Clinic experience. West J Med 1995;163:133-8.

38. Carey EJ, Douglas DD, Balan V, Vargas HE, Byrne TJ, Moss $\mathrm{AA}$, et al. Hepatopulmonary syndrome after living donor liver transplantation and deceased donor liver transplantation: a single-center experience. Liver Transpl 2004;10:529-33. doi: 10.1002/lt.20127.

39. Fallon MB, Abrams GA. Pulmonary dysfunction in chronic liver disease. Hepatology 2000;32:859-65. doi: 10.1053/ jhep.2000.7519.
40. Krowka MJ, Dickson ER, Cortese DA. Hepatopulmonary syndrome. Clinical observations and lack of therapeutic response to somatostatin analogue. Chest 1993;104:515-21. doi: 10.1378/chest.104.2.515.

41. Krowka MJ, Mandell MS, Ramsay MA, Kawut SM, Fallon MB, Manzarbeitia C, et al. Hepatopulmonary syndrome and portopulmonary hypertension: a report of the multicenter liver transplant database. Liver Transpl 2004;10:174-82. doi: 10.1002/1t.20016.

42. Schenk P, Schoniger-Hekele M, Fuhrmann V, Madl C, Silberhumer G, Muller C. Prognostic significance of the hepatopulmonary syndrome in patients with cirrhosis. Gastroenterology 2003;125:1042-52. doi: 10.1016/s0016-5085(03)01207-1.

43. Arguedas MR, Abrams GA, Krowka MJ, Fallon MB. Prospective evaluation of outcomes and predictors of mortality in patients with hepatopulmonary syndrome undergoing liver transplantation. Hepatology 2003;37:192-7. doi: 10.1053/ jhep.2003.50023.

44. Krowka MJ, Wiseman GA, Burnett OL, Spivey JR, Therneau T, Porayko MK, et al. Hepatopulmonary syndrome: a prospective study of relationships between severity of liver disease, $\mathrm{PaO}(2)$ response to $100 \%$ oxygen, and brain uptake after (99m) Tc MAA lung scanning. Chest 2000;118:615-24. doi: 10.1378/chest.118.3.615.

45. Grilo-Bensusan I, Pascasio-Acevedo JM. Hepatopulmonary syndrome: What we know and what we would like to know. World J Gastroenterol 2016;22:5728-41. doi: 10.3748/wjg. v22.i25.5728.

46. Porres-Aguilar M, Altamirano JT, Torre-Delgadillo A, Charlton MR, Duarte-Rojo A. Portopulmonary hypertension and hepatopulmonary syndrome: a clinicianoriented overview. Eur Respir Rev 2012;21:223-33. doi: 10.1183/09059180.00007211.

47. Porres-Aguilar M, Zuckerman MJ, Figueroa-Casas JB, Krowka MJ. Portopulmonary hypertension: state of the art. Ann Hepatol 2008;7:321-30.

48. Cosarderelioglu C, Cosar AM, Gurakar M, Pustavoitau A, Russell SD, Dagher NN, et al. Portopulmonary Hypertension and Liver Transplant: Recent Review of the Literature. Exp Clin Transplant 2016;14:113-20.

49. Hadengue A, Benhayoun MK, Lebrec D, Benhamou JP. Pulmonary hypertension complicating portal hypertension: prevalence and relation to splanchnic hemodynamics. Gastroenterology 1991;100:520-8. doi: 10.1016/00165085(91)90225-a.

50. Colle IO, Moreau R, Godinho E, Belghiti J, Ettori F, CohenSolal A, et al. Diagnosis of portopulmonary hypertension in candidates for liver transplantation: a prospective study. Hepatology 2003;37:401-9. doi: 10.1053/jhep.2003.50060.

51. Humbert M, Sitbon O, Chaouat A, Bertocchi M, Habib G, Gressin V, et al. Pulmonary arterial hypertension in France: results from a national registry. Am J Respir Crit Care Med 2006;173:1023-30. doi: 10.1164/rccm.200510-1668OC. 
52. Moller S, Krag A, Henriksen JH, Bendtsen F. Pathophysiological aspects of pulmonary complications of cirrhosis. Scand J Gastroenterol 2007;42:419-27. doi: 10.1080/00365520601151695.

53. Le Pavec J, Souza R, Herve P, Lebrec D, Savale L, Tcherakian $\mathrm{C}$, et al. Portopulmonary hypertension: survival and prognostic factors. Am J Respir Crit Care Med 2008;178:637-43. doi: 10.1164/rccm.200804-613OC.

54. Ramsay M. Portopulmonary hypertension and right heart failure in patients with cirrhosis. Curr Opin Anaesthesiol 2010;23:145-50. doi: 10.1097/ACO.0b013e32833725c4.

55. Currie PJ, Seward JB, Chan KL, Fyfe DA, Hagler DJ, Mair $\mathrm{DD}$, et al. Continuous wave Doppler determination of right ventricular pressure: a simultaneous Doppler-catheterization study in 127 patients. $J$ Am Coll Cardiol 1985;6:750-6. doi: 10.1016/s0735-1097(85)80477-0.

56. Douglas PS, Khandheria B, Stainback RF, Weissman NJ, Brindis RG, Patel MR, et al. ACCF/ASE/ACEP/ASNC/ SCAI/SCCT/SCMR 2007 appropriateness criteria for transthoracic and transesophageal echocardiography: a report of the American College of Cardiology Foundation Quality Strategic Directions Committee Appropriateness Criteria Working Group, American Society of Echocardiography, American College of Emergency Physicians, American Society of Nuclear Cardiology, Society for Cardiovascular Angiography and Interventions, Society of Cardiovascular Computed Tomography, and the Society for Cardiovascular Magnetic Resonance endorsed by the American College of Chest Physicians and the Society of Critical Care Medicine. J Am Coll Cardiol 2007;50:187-204. doi: 10.1016/j.jacc.2007.05.003.

57. Kim WR, Krowka MJ, Plevak DJ, Lee J, Rettke SR, Frantz $\mathrm{RP}$, et al. Accuracy of Doppler echocardiography in the assessment of pulmonary hypertension in liver transplant candidates. Liver Transpl 2000;6:453-8. doi: 10.1053/jlts.2000.7573.

58. D'Alto M, Romeo E, Argiento P, D'Andrea A, Vanderpool $\mathrm{R}$, Correra A, et al. Accuracy and precision of echocardiography versus right heart catheterization for the assessment of pulmonary hypertension. Int J Cardiol 2013;168:4058-62. doi: 10.1016/j.ijcard.2013.07.005.

59. Meyer CA, White CS, Sherman KE. Diseases of the hepatopulmonary axis. Radiographics 2000;20:687-98. doi: 10.1148/radiographics.20.3.g00ma17687.

60. Fujii M, Adachi S, Shimizu T, Hirota S, Sako M, Kono M. Interstitial lung disease in rheumatoid arthritis: assessment with high-resolution computed tomography. J Thorac Imaging 1993;8:54-62.

61. Gabbay E, Tarala R, Will R, Carroll G, Adler B, Cameron $\mathrm{D}$, et al. Interstitial lung disease in recent onset rheumatoid arthritis. Am J Respir Crit Care Med 1997;156:528-35. doi: 10.1164/ajrccm.156.2.9609016.

62. Curtis JR, Beukelman T, Onofrei A, Cassell S, Greenberg $\mathrm{JD}$, Kavanaugh A, et al. Elevated liver enzyme tests among patients with rheumatoid arthritis or psoriatic arthritis treated with methotrexate and/or leflunomide. Ann Rheum
Dis 2010;69:43-7. doi: 10.1136/ard.2008.101378.

63. Sokolove J, Strand V, Greenberg JD, Curtis JR, Kavanaugh A, Kremer JM, et al. Risk of elevated liver enzymes associated with TNF inhibitor utilisation in patients with rheumatoid arthritis. Ann Rheum Dis 2010;69:1612-7. doi: 10.1136/ ard.2009.112136.

64. Cojocaru M, Cojocaru IM, Silosi I, Vrabie CD. Pulmonary manifestations of systemic autoimmune diseases. Maedica 2011;6:224-9.

65. Abraham S, Begum S, Isenberg D. Hepatic manifestations of autoimmune rheumatic diseases. Ann Rheum Dis 2004;63:123-9. doi: 10.1136/ard.2002.001826.

66. Liberal R, Grant CR. Cirrhosis and autoimmune liver disease: Current understanding. World J Hepatol 2016;8:1157-68. doi: 10.4254/wjh.v8.i28.1157.

67. Carbone M, Neuberger JM. Autoimmune liver disease, autoimmunity and liver transplantation. J Hepatol 2014;60:210-23. doi: 10.1016/j.jhep.2013.09.020.

68. Shaw M, Collins BF, Ho LA, Raghu G. Rheumatoid arthritisassociated lung disease. Eur Respir Rev 2015;24:1-16. doi: 10.1183/09059180.00008014.

69. Shen M, Zhang F, Zhang X. Primary biliary cirrhosis complicated with interstitial lung disease: a prospective study in 178 patients. J Clin Gastroenterol 2009;43:676-9. doi: 10.1097/ MCG.0b013e31818aa11e.

70. Hartleb M, Gutkowski K, Milkiewicz P. Nodular regenerative hyperplasia: evolving concepts on underdiagnosed cause of portal hypertension. World J Gastroenterol 2011;17:1400-9. doi: 10.3748/wjg.v17.i11.1400.

71. Guo L, Zhou L, Zhang N, Deng B, Wang B. Extrahepatic Autoimmune Diseases in Patients with Autoimmune Liver Diseases: A Phenomenon Neglected by Gastroenterologists. Gastroenterol Res Pract 2017;2017:2376231. doi: $10.1155 / 2017 / 2376231$.

72. Cardenas A, Kelleher T, Chopra S. Review article: hepatic hydrothorax. Aliment Pharmacol Ther 2004;20:271-9. doi: 10.1111/j.1365-2036.2004.02081.x

73. Siddappa PK, Kar P. Hepatic hydrothorax. Trop Gastroenterol 2009;30:135-41.

74. Badillo R, Rockey DC. Hepatic hydrothorax: clinical features, management, and outcomes in 77 patients and review of the literature. Medicine 2014;93:135-42. doi: 10.1097/ MD.0000000000000025.

75. Strauss RM, Boyer TD. Hepatic hydrothorax. Semin Liver Dis 1997;17:227-32. doi: 10.1055/s-2007-1007200.

76. Garbuzenko DV, Arefyev NO. Hepatic hydrothorax: An update and review of the literature. World J Hepatol 2017;9:1197-204. doi: 10.4254/wjh.v9.i31.1197.

77. Al-Zoubi RK, Abu Ghanimeh M, Gohar A, Salzman GA, Yousef O. Hepatic hydrothorax: clinical review and update on consensus guidelines. Hospital practice (1995) 2016;44:21323. doi: 10.1080/21548331.2016.1227685. 
78. Soin S, Sher N, Saleem N. Spontaneous bacterial empyema: an elusive diagnosis in a patient with cirrhosis. BMJ Case Rep 2018;2018:bcr2018224810. doi: 10.1136/bcr-2018-224810.

79. Guarner C, Soriano G. Bacterial translocation and its consequences in patients with cirrhosis. Eur J Gastroenterol Hepatol 2005;17:27-31. doi: 10.1097/00042737-200501000-00006.

80. Chen T-A, Lo G-H, Lai K-H. Risk factors for spontaneous bacterial empyema in cirrhotic patients with hydrothorax. $J$ Chin Med Assoc 2003;66:579-86.

81. Chen C-H, Shih C-M, Chou J-W, Liu Y-H, Hang L-W, Hsia T-C, et al. Outcome Predictors of Cirrhotic Patients With Spontaneous Bacterial Empyema. Liver Int 2011;31:417-24. doi: 10.1111/j.1478-3231.2010.02447.x 